\title{
Agronomic biofortification of carrot with selenium
}

\author{
Biofortificação agronômica da cenoura com selênio
}

\author{
Vanuze Costa de Oliveira ${ }^{1 *}$, Valdemar Faquin ${ }^{1}$, Karina Carvalho Guimarães² ${ }^{2}$ Fabrício Ribeiro Andrade ${ }^{3}$, \\ Joelma Pereira², Luiz Roberto Guimarães Guilherme
}

\author{
'Universidade Federal de Lavras/UFLA, Departamento de Ciência do Solo/DCS, Lavras, MG, Brasil \\ 2Universidade Federal de Lavras/UFLA, Departamento de Ciência dos Alimentos/DCA, Lavras, MG, Brasil \\ ${ }^{3}$ Instituto Federal do Mato Grosso/IFMT, Juína, MT, Brasil \\ *Corresponding author: vanuze.costa@gmail.com \\ Received in November 24, 2017 and approved in April 23, 2018
}

\begin{abstract}
The selenium (Se) is essential for human metabolism, but a large part of the world's population has deficiency in this element. This can be reversed by the consumption of biofortified foods, given that plants can efficiently act in controlling excessive and/or accidental consumption of an element that can occur in humans through the use of dietary supplements. The objective of this study was to evaluate the effect of different application forms and sources of Se in the growth, production, nutrition, physical-chemical characteristics, content and accumulation of Se in carrots. The experiment was conducted under greenhouse conditions, using pots containing $4 \mathrm{dm}^{3}$ of Red-yellow Latosol. A completely randomized design was used in a $2 \times 2 \times 2$ factorial scheme (with and without Se application, two sources of Se: selenate and selenite, two forms of application of Se: soil and foliar applications), with five replicates. Foliar application of selenate increased the yield and titratable acidity, reducing root ripening index. Foliar application of selenite increased the content of Se in the shoots and the content of carotenoids in the roots. Both sources of Se (selenate and selenite) and application forms (soil or foliar application) increased their content in the roots. However, the foliar application of selenate was the most effective source and form of application. Therefore, it is possible to increase the contents of Se in the edible part of carrots, favoring the consumption of this element by the population.
\end{abstract}

Index terms: Daucus carota Lam; selenate; selenite; maturation index; carotenoids.

\begin{abstract}
RESUMO
O selênio (Se) é essencial para o metabolismo humano, porém, grande parte da população mundial apresenta deficiência nesse elemento. Isto pode ser revertido pelo consumo de alimentos biofortificados, uma vez que as plantas podem atuar de forma eficiente no controle do consumo excessivo e / ou acidental de um elemento que pode ocorrer nos seres humanos através do uso de suplementos dietéticos. Objetivou-se com o presente estudo avaliar o efeito de formas de aplicação e fontes de Se no crescimento, produção, nutrição, características físico-químicas, teor e acúmulo de Se na cenoura. O experimento foi desenvolvido em casa de vegetação, utilizando vasos com quatro dm ${ }^{3}$ contendo Latossolo Vermelho Amarelo. Adotou-se o delineamento inteiramente casualizado, em fatorial $2 \times 2 \times 2$ (com e sem aplicação do Se; duas fontes do Se: selenato e selenito; duas formas de aplicação do Se: via solo e foliar), com cinco repetições. O selenato aplicado via foliar aumenta a produção e a acidez titulável e reduz o índice de maturação das raízes. O selenito via foliar aumenta o teor de Se na parte aérea e o teor de carotenoides nas raízes de cenoura. As duas fontes de Se (selenato e selenito) e formas de aplicação (via solo ou foliar) promovem aumento do seu teor nas raízes de cenoura, porém o selenato via foliar é a fonte e forma mais efetiva. Dessa forma, é possível aumentar os teores de Se na parte comestível da cenoura e, assim, favorecer a ingestão desse elemento pela população.
\end{abstract}

Termos para indexação: Daucus carota Lam; selenato; selenito; índice de maturação; carotenoides.

\section{INTRODUCTION}

Selenium (Se) is an essential trace element for animals and humans. It acts in the antioxidant system as a key component of selenoproteins and selenoenzymes, with important biological functions (Rayman, 2002). In addition, it can act in the formation of hormones, in DNA synthesis, fertility, reproduction, increasing muscle functions, and delaying the aging process (Suttle, 2010; Cabaraux et al., 2006). Furthermore, there are reports of cancer prevention through the action of selenoenzymes, which reduce damages caused to the DNA and decreases reactive oxygen species, increasing the production of tumor suppressor proteins (Almondes et al., 2010).

Despite its essential nature, Se deficiency affects hundreds of millions of people in the world, and is relevant in several regions of Brazil, indicating the need to adopt strategies to increasing Se consumption. Plants play a key role in introducing Se into the food chain. Thus, biofortification (increasing the content of a certain element in edible parts of plants) can be an important technique to 
increase the consumption of the element by animals and humans.

Although selenium has not been demonstrated to be essential in plants, many studies show that, when supplied in low doses, Se benefits plant growth and production (Kápolna et al., 2009; Ramos et al., 2011; Boldrin et al., 2013; Zhu et al., 2017).

The success of biofortification depends on several factors, specially type of crop, when considering acceptance and consumption by the population. Studies have shown the success of biofortification with Se in lettuce, rice, wheat and broccoli (Ramos et al., 2011; Boldrin et al., 2013; Zembala et al., 2010; Ávila et al., 2014). In this sense, carrot (Daucus carota L.), a widely consumed vegetable, renders great potential to this practice, since it presents a high content of carotenoids. These pigments are precursors of vitamin A and have an antioxidant effect in the human body, inhibiting the action of free radicals, which are harmful to cells and are associated with the development of diseases such as cancer, cataracts and arteriosclerosis.

Research has already shown that carrots are highly efficient in absorbing and metabolizing Se, when supplied at low doses via the leaf (Kápolna et al., 2009) and soil (Bañuelos et al., 2015; Smoleń et al., 2016). However, there are few studies focusing on this specie.

When considering biofortification programs with $\mathrm{Se}$, it is important to consider the chemical form of $\mathrm{Se}$ that is to be applied, as well as the form of application. Selenate $\left(\mathrm{SeO}_{4}^{2-}\right)$ and selenite $\left(\mathrm{SeO}_{3}{ }^{2-}\right)$ are the inorganic forms of the element with the highest potential for absorption and bioaccumulation by plants. Selenite has a strong interaction with the clay fraction of a large portion of the soils cultivated in tropical and subtropical regions, therefore, less availability when compared to selenate (Yläranta, 1984; Martínez et al., 2006; Li; McGrath; Zhao, 2008). Moreover, after absorption by the roots, selenate presents greater mobility in the xylem, whereas selenite is rapidly assimilated into organic compounds with low mobility (Li; McGrath; Zhao, 2008). On the other hand, when applied via the leaf, selenite tends to accumulate more in the aerial part than selenate, as verified by Yläranta (1984), when studying Phleum pratense $\mathrm{L}$.

Therefore, considering the essentiality of Se to humans, and the importance of carrot in the global food scenario, this study aimed at evaluating the effect of different forms of application and sources of Se in the production of plant dry mass and fresh roots, physicochemical characteristics and carotenoid concentration in roots, as well as in the macro and micronutrient contents in the shoot and roots of carrots.

\section{MATERIAL AND METHODS}

\section{Conduction of the experiment and experimental design}

The experiment was conducted under greenhouse conditions at the Department of Soil Science at the Universidade Federal de Lavras, using $4 \mathrm{~kg}$ pots, filled with dystrophic Red-Yellow Latosol (LVAd) collected in the $0-20 \mathrm{~cm}$ layer. Chemical and physical soil characterization was performed according to the methods described by Embrapa (1997), presenting the following values: $\mathrm{pH}$ in water: 4.8; P-mehlich-1: $1.1 \mathrm{mg} \mathrm{dm}^{-3}$; P-resine: $26.6 \mathrm{mg}$ $\mathrm{dm}^{-3} ; \mathrm{K}: 32 \mathrm{mg} \mathrm{dm}^{-3}$; Ca: $0.3 \mathrm{cmol}_{\mathrm{c}} \mathrm{dm}^{-3} ; \mathrm{Mg}^{-3} 0.1 \mathrm{cmol}_{\mathrm{c}}$ $\mathrm{dm}^{-3} ; \mathrm{Al}: 0.6 \mathrm{cmol}_{\mathrm{c}} \mathrm{dm}^{-3} ; \mathrm{H}+\mathrm{Al}: 4.5 \mathrm{cmol} \mathrm{dm}^{-3}$; SB: 0.5 cmol dm${ }^{-3}$; SOM: $1.6 \%$; V: 9.6\%; t: $1.1 \mathrm{cmol} \mathrm{dm}^{-3}$; T: 5.0 cmol dm${ }^{-3} ; \mathrm{m}: 55.5 \%$; S: $9.9 \mathrm{mg} \mathrm{dm}^{-3} ; \mathrm{Zn}: 0.5 \mathrm{mg} \mathrm{dm}^{-3}$; B: $0.2 \mathrm{mg} \mathrm{dm}^{-3}$; Fe: $41.6 \mathrm{mg} \mathrm{dm}^{-3}$; Mn: $4.1 \mathrm{mg} \mathrm{dm}^{-3}$; Cu: 0.5 mg dm${ }^{-3}$; sand: $740 \mathrm{~g} \mathrm{~kg}^{-1}$; silt: $30 \mathrm{~g} \mathrm{~kg}^{-1}$; clay: $230 \mathrm{~g} \mathrm{~kg}^{-1}$. The natural content of Se in the soil, analyzed according to Ramos et al. (2010), was of $0.065 \mathrm{mg} \mathrm{dm}^{-3}$.

The experiment was conducted in a completely randomized design, using five replicates, with $2 \times 2 \times 2$ factorial scheme, considering the presence and absence of $\mathrm{Se}$; two sources of $\mathrm{Se}$ (sodium selenate - $\mathrm{Na}_{2} \mathrm{SeO}_{4}$ and sodium selenite - $\mathrm{Na}_{2} \mathrm{SeO}_{3}$ ), and two forms of application (soil and foliar application at the doses of $1.0 \mathrm{mg} \mathrm{dm}^{-3}$ and $50 \mu \mathrm{m} \mathrm{L}^{-1}$, respectively). Each experimental unit consisted of six plants per pot. The concentration of Se in foliar application was chosen within the range suggested by Kápolna et al. (2009) for carrot, and the same applied by Boldrin et al. (2013) in rice.

Based on the soil chemical analysis, liming was performed aiming to increase base saturation to $70 \%$, using dolomitic limestone (CaO: $37 \%$, $\mathrm{MgO}: 15 \%$ and RTNP: $85 \%$ ). The soil was incubated for 30 days, with humidity close to $60 \%$ of the total pore volume. Planting and cover fertilization were performed according to Malavolta (1980): $300 \mathrm{mg} \mathrm{dm}^{-3}$ of $\mathrm{N}$ and $150 \mathrm{mg} \mathrm{dm}^{-3}$ of K (divided into three applications); $200 \mathrm{mg} \mathrm{dm}^{-3}$ of P; $50 \mathrm{mg} \mathrm{dm}^{-3}$ of $\mathrm{S} ; 1.5 \mathrm{mg} \mathrm{dm}^{-3}$ of Cu; $5 \mathrm{mg} \mathrm{dm}^{-3}$ of $\mathrm{Zn}$ and $0.1 \mathrm{mg} \mathrm{dm}^{-3}$ of Mo per pot. The application of Se in the soil was carried out together with the fertilization of planting.

After fertilization, a total of 15 carrot seeds (Daucus carota L. cv Brasília) were sown in each vase and cut to six seedlings at 14 days after emergence. The foliar application of Se was applied 45 days after sowing (DAS), in the morning (between 8:30 and 9:30 h), using 
a $\mathrm{CO} 2$ pressurized sprayer with a constant pressure of 2.8

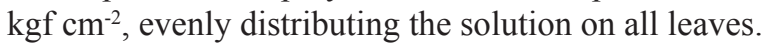

\section{Growth, root production and nutrient contents}

At the end of the experiment, plants were separated in aerial part and roots. The roots were washed and weighed to determine fresh mass production. Two roots of each plot were separated for physico-chemical analysis: soluble solids (SS), titratable acidity (TA), maturation index (MI), $\mathrm{pH}$ and carotenoid contents.

The remaining roots and aerial parts of the plants were dried in a forced air circulation oven at $65^{\circ} \mathrm{C}$ for $72 \mathrm{~h}$ until constant weight, and the aerial dry mass (ADM) was determined. The parts were ground in a Willey type mill with $1.0 \mathrm{~mm}$ (20 mesh) mesh sieves, digested, determining the contents of macro and micronutrients according to the methodology described by Malavolta, Vitti and Oliveira (1997).

\section{Physico-chemical characteristics and carotenoid content of roots}

The determination of soluble solids ( ${ }^{\circ}$ Brix) (SS) and $\mathrm{pH}$ in fresh root samples was done according to the methodology proposed by AOAC (2010), the titratable acidity (TA) was obtained according to the IAL method (2008) and the maturation index (MI) was obtained by the relationship between soluble solids and titratable acidity, according to Tressler and Joslyn (1961). Carotenoids were determined according to the methodology proposed by Rodriguez-Amaya (2001).

\section{Determination of Se contents}

For the determination of Se contents, $0.5 \mathrm{~g}$ of dry tissues (shoot and roots) were digested in $6 \mathrm{~mL}$ of a mixture of nitric acid $\left(\mathrm{HNO}_{3}-\geq 65 \%\right)$ and perchloric acid $\left(\mathrm{HClO}_{4}\right.$ - $69.72 \%$ ) in a $2: 1$ ratio. The digestion was performed in a digestion block for $2 \mathrm{~h}$; (initial temperature $50^{\circ} \mathrm{C}$ ) until complete digestion, the temperature was gradually increased $\left(50{ }^{\circ} \mathrm{C}\right.$ every $\left.30 \mathrm{~min}\right)$ for $2 \mathrm{~h}$ until reaching a final temperature of $200{ }^{\circ} \mathrm{C}$. Ten milliliters of deionized water was added after cooling.

A sample with a standard reference material (White Clover - BCR 402, Institute for Reference Materials and Measurements, Geel, Belgium) of known content (6.7 $\mathrm{mg} \mathrm{kg}^{-1}$ ) was included in each digestion battery for quality control. The mean recovery for Se in this reference material was of $89.4 \%(n=4)$. The extracts were analyzed by atomic absorption spectroscopy with electro-thermal atomization in a graphite furnace (Perkin Elmer, model AA-analyst 800, Midland, Canada).

\section{Statistical analysis}

The normality of the data was analyzed using the Anderson-Darling test and the homoscedasticity of the data was verified with the variance equation test (or Leven's test). After the data were submitted to analysis of variance and the significance was verified by the $F$ test, the Scott-Knott test was performed at a level of 5\% of probability $(\mathrm{p}<0.05)$, using the statistical program SISVAR (Ferreira, 2011). Graphs were built using the Sigma Plot 12.5 software (Systat Software, Inc., San Jose, CA, USA).

\section{RESULTS AND DISCUSSION}

\section{Production of dry shoot mass and fresh root mass}

The production of dry shoot mass (DSM) was significantly affected $(\mathrm{p} \leq 0.05)$ by both the presence and the form of Se application, as well as by the interaction between these factors, while the production of fresh roots was altered by the forms and sources of Se, and by the interaction of these factors (Figure 1). However, when Se was applied on the leaves, there was an increase of $14 \%$ in relation to the control, and of $16 \%$ in relation to soil application (Figure 1A).

Regarding the production of fresh roots, there was no influence of Se application via soil, regardless of the source (Figure 1B). On the other hand, foliar application of selenate increased root yield by $73 \%$ in relation to the control, and by $70 \%$ when compared to soil application. No difference was observed between selenite and control.

Although Se is not considered essential for plants, several studies have shown that, in low concentrations, this element has beneficial effect over growth and stress tolerance, by increasing the antioxidant capacity of plants through the activation of enzymes superoxide dismutase, catalase, glutathione peroxidase, decreasing reactive oxygen species and lipid peroxidation (Djanaguiraman et al., 2005; Xue; Hartikainen; Piironen, 2001). However, agricultural crops are sensitive to high concentrations of $\mathrm{Se}$ in their tissue, with sensitivity varying among plant species (Lyons et al., 2005), requiring care when establishing doses of Se.

\section{Physical-chemical characteristics and carotenoid contents in the roots}

The physical-chemical characteristics of carrot roots were significantly affected $(\mathrm{p} \leq 0.05)$ by the application forms and sources of Se, as well as by the interaction of these factors (Figure 2). 

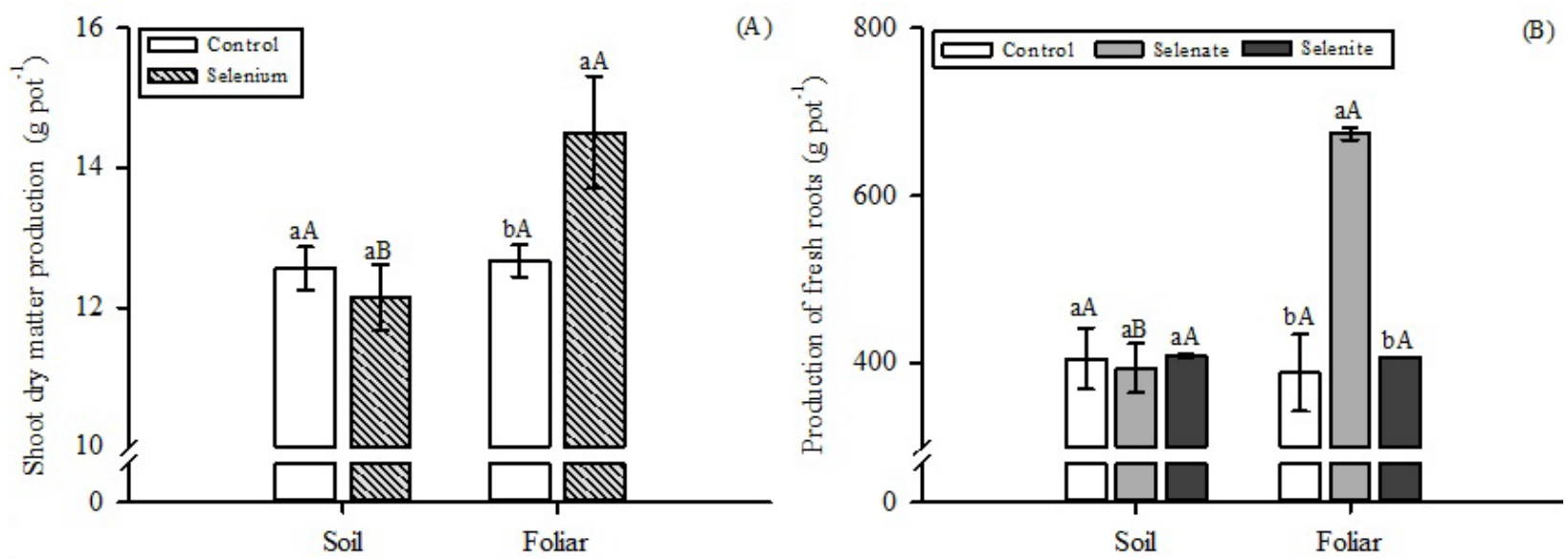

Figure 1: Production of dry shoot mass (A) and fresh roots (B) of carrot plants according to the sources and application of Se. (A): uppercase letters compare the presence and absence of Se in each form of application and upper and lower case letters compare the forms of application of Se in the presence or absence of Se. Same letters mean they do not differ from each other ( $F$ test, $p<0.05)$; $(B)$ : lowercase letters compare the sources of Se in each form of application and uppercase letters compare the application forms of Se in each source. Same letters mean they do not differ from each other (Scott-Knott test, $p<0.05$ ). Vertical bar indicates the standard error of the mean $(n=5)$.

Soluble solids (SS) contents were increased by the application of selenate via soil (35\%) and via foliar (7\%), while, with selenite, the effect occurred only for foliar application, with a $23 \%$ increase in relation to the control (Figure 2A). Selenate applied via soil was more efficient than its foliar supply while the opposite was observed for selenite.

Soluble solids influence the taste of the products and are represented by acids, salts, vitamins, amino acids, sugars and other substances important for food quality. Therefore, the use of Se improved the flavor of the carrot, which also occurred in pear fruits when applying the element in the form of selenate (Pezzarossa et al., 2012). The knowledge of the influence of Se in characteristics such as SS ( ${ }^{\circ}$ Brix) of vegetable crops is important because the consumer has preference for products with higher levels of SS, thus greater sweetness, especially when destined for in natura consumption or in salads, as is the case of carrots (Nascimento; Cardoso; Cocozza, 2014).

Increased titratable acidity (TA) was detected when Se was applied in the soil by both sources. An increase in TA was detected when applying Se via soil for both sources. This also occurred when applying selenite via foliar, with more pronounced effect when applying selenite via soil (Figure 2B). Similar behavior was observed for root $\mathrm{pH}$ (Figure 2C).
The TA and $\mathrm{pH}$ of vegetables crops are related to the food quality, given that they are linked to their flavor and aroma, which are very important for consumer acceptance. The $\mathrm{pH}$ values found in this study are within those expected for carrots, since this culture is classified as a low acid food. Silva et al. (2016) found a similar $\mathrm{pH}$ value (6.0) when studying carrots.

In relation to the maturation index (MI), when Se was supplied via soil, there was a reduction of $54 \%$ when selenate was applied, and of $64 \%$ when selenite was used, in relation to that obtained in the control plants (Figure 2D). On the other hand, foliar application of selenate reduced MI by approximately $45 \%$, while selenite did not differ from control.

The MI is inversely proportional to the titratable acidity, which is related to the fact that the organic acids are used during maturation process, either through respiration or transformation into sugars (Lombardi; Moraes; Camelatto, 2000; Matarazzo et al., 2013). In a research conducted with tomatoes, Zhu et al. (2017) observed lower fruit maturation rates when plants were treated with $1 \mathrm{mg}$ $\mathrm{L}^{-1}$ of $\mathrm{Se}$ in the form of selenite. The authors related this behavior to the interference of $\mathrm{Se}$ in the production of ethylene. In addition, the maturation delay of the fruits can be related to the antioxidant effect of the element, as evidenced by Zhu et al. (2016) in tomato plants grown in the presence of selenate. 

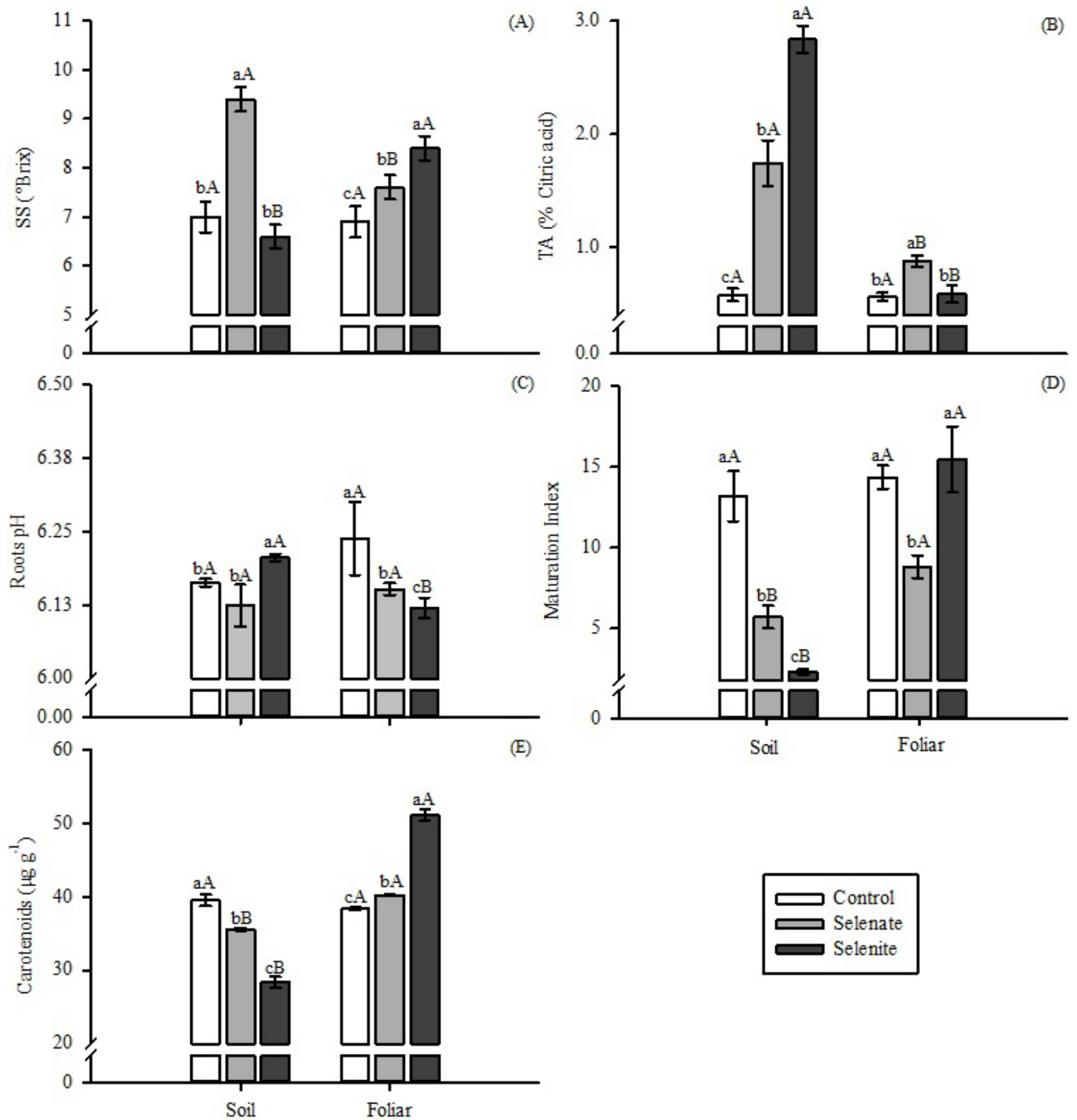

Figure 2: Soluble solids (A), titratable acidity (B), $\mathrm{pH}(\mathrm{C})$, maturation index (D) and carotenoid content (E) in carrot roots according to sources and application of Se. Lowercase letters compare sources (Scott-Knott's test, p<0.05) in each application form, and uppercase letters compare application forms ( $F$ test, $p<0.05)$ in each source. Same letters mean they do not differ from each other ( $F$ test, $p<0.05)$. Vertical bar indicates the standard error of the mean $(n=5)$. 
Carotenoid content in the roots was affected by the interaction between the forms of application and the sources of Se (Figure 2E). The application of Se in the soil reduced the levels of carotenoids for both sources. On the other hand, foliar application promoted increases of 7 and $33 \%$ for selenate and selenite, respectively, in relation to the control. Several factors may influence carotenoid content, among which RodriguezAmaya (2001) highlights maturation degree.

Furthermore, carotenoids are compounds with a protective function in plants, acting against possible oxidative damages. Selenite presents a higher phytotoxicity when compared to selenate (Ríos et al., 2010; Guerrero et al., 2014; González-Morales et al., 2017). Therefore, an increase in carotenoid content was observed when foliar selenite was applied. When applied in the soil, this source of Se did not influence carotenoids. Thus, the increase in carotenoid production when foliar selenite was applied may be related to the natural protection process of plants against a possible phytotoxicity caused by selenite (Figure $2 \mathrm{E}$ ).

\section{Nutrient contents}

The contents of potassium $(\mathrm{K})$ and iron $(\mathrm{Fe})$ in the shoots, and of manganese $(\mathrm{Mn})$ and iron $(\mathrm{Fe})$ in the roots, were significantly affected $(\mathrm{p} \leq 0.05)$ by the interaction between sources and forms of application of Se (Figure 3 ). The other nutrients were not influenced by the treatments.

Selenate application in the soil caused a reduction of $26 \%$ of $\mathrm{K}$ when compared to the control, where as selenite treatment did not differ from the control. On the other hand, the supply of Se via foliar did not affect the contents of $\mathrm{K}$ in the aerial part of the plants, regardless of the source used (Figure 3A).

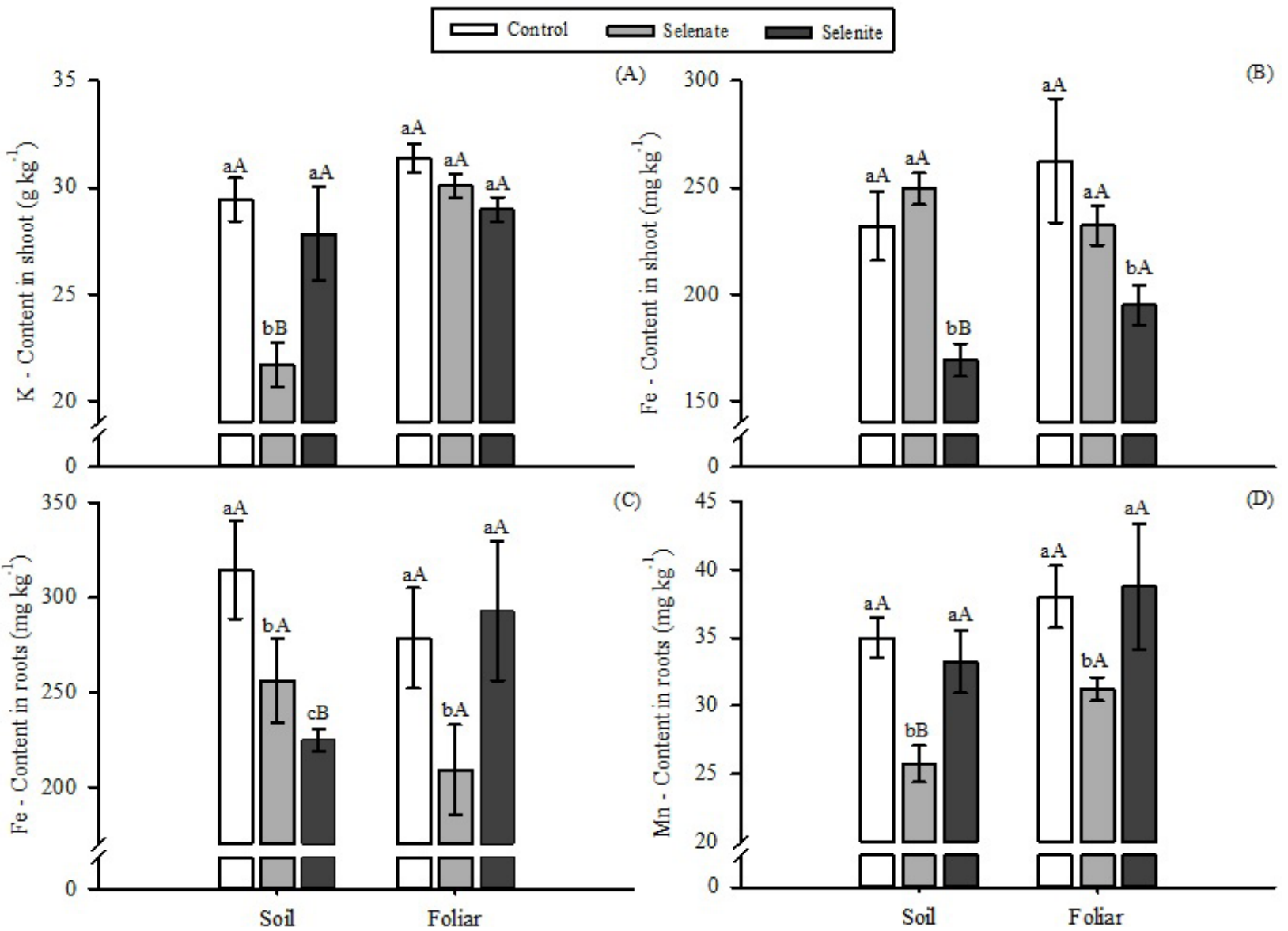

Figure 3: Contents of $\mathrm{K}$ and Fe $(\mathrm{A}$ and $\mathrm{B})$ in the shoots and of Fe and $\mathrm{Mn}(\mathrm{C}$ and $\mathrm{D})$ in the roots, from different Se sources and forms of application. Lowercase letters compare sources (Scott-Knott's test, p<0.05) in each application form and uppercase letters compare application forms ( $F$ test, $p<0.05$ ) in each source. Same letters mean they do not differ from each other. Vertical bar indicates the standard error of the mean $(n=5)$. 
Drahonovský et al. (2016) detected reduction in $\mathrm{K}$ content in wild plant species when applicated $1 \mathrm{ppm}$ of Selenium, compared to control plants. However, there are few studies justifying the possible reduction of $\mathrm{K}$ when selenate is applied in plants. In this sense, Filek et al. (2010) relate the lower K content to the role of this ion in the osmotic regulation of cells, as well as may be related to an excess of ion input in the cells. That can also be applied to carrot plants.

The application of Se as selenite promoted a reduction in the content of $\mathrm{Fe}$ in the aerial part of the plants in both forms of application. The greatest reduction was observed for soil application (Figure 3B). The application of both forms of Se in the soil, and as selenate in foliar application, reduced the content of Fe in the roots (Figure 3C). For wheat grown in nutrient solution, Guerrero et al. (2014) observed that, when plants were submitted to different concentrations of Se (selenate and selenite), there was a reduction in $\mathrm{Fe}$ content in the aerial part and in the roots. For rapeseed, Zembala et al. (2010) detected a reduction in Fe content in the roots when Se was applied in the soil as selenate.

The application of selenite by both application forms reduced Mn levels in the roots (Figure 3D). Zembala et al. (2010), in a study conducted with rapeseed, found similar patterns. For selenite, the forms of application did not affect the contents of $\mathrm{Mn}$ in the roots.

\section{Content and accumulation of Se}

The levels of Se in the shoot and roots, and the accumulation of Se in the aerial part of carrot plants, were significantly influenced $(\mathrm{p} \leq 0.05)$ by the sources and forms of application of Se, as well as by the interaction between factors (Figure 4). There was an increase in Se content in the shoots (Figure 4A) and roots (Figure 4B) regardless of the form or source of Se application.

When Se was supplied via soil, the highest Se content was observed for selenite. However, the opposite was obtained when Se was applied via foliar (Figure 4A). In the roots (Figure 4B), the concentration was always higher when selenate was applied, either via soil or foliar application. This pattern was found for species such as wheat, rice, cabbage, tomato, and carrot (Li; McGrath; Zhao, 2008; Boldrin et al., 2013, Avila et al., 2014; Zhu et al., 2016; Kápolna et al., 2009).

When compared to the control treatment, the presence of Se as selenate promoted an increase of Se 2028 and 3570 times higher in the roots when applied to soil and leaves, respectively (Figure 4B). Similar results were observed by Kápolna et al. (2009), in a study conducted with foliar application of Se in the form of selenate in carrot plants.

The highest accumulation of Se in the shoots was observed with foliar application of selenite (Figure 4C), which is similar to the findings of previous studies (Cartes; Gianfreda; Mora, 2005; Sors; Ellis; Salt, 2005; Boldrin et al., 2013). In general, foliar application promoted greater accumulation of Se in the aerial part regardless of the source used. When selenite is applied to soil, it tends to accumulate in a greater proportion in the roots (Boldrin et al., 2013, Guerrero et al., 2014; Smoleń et al., 2016), and when supplied via foliar, it accumulates more in the shoots.

In the interior of the plants, differences in the mobility of selenate and selenite have been reported, and it has been proven that the transport of selenate to shoot is faster than that of selenite (Zhang et al., 2003). After absorption by the roots, selenite is rapidly converted into organic forms, such as selenomethionine (Zayed; Lytle; Terry, 1998), and stored in the roots. Thus, it can be assumed that the same occurs when selenite is applied via foliar, accumulating in the aerial part of the plant.

Furthermore, studies conducted under field conditions and greenhouse have demonstrated the higher efficiency of selenate for Se biofortification when compared to selenite (Cartes; Gianfreda; Mora, 2005; Boldrin et al., 2013). This was also demonstrated in hydroponic cultivation (Ramos et al., 2011).

The most efficient way for Se absorption and metabolism in the human organism is the organic form found in vegetables, which makes them the most suitable products for the insertion of Se and other essential elements in the human food chain. Plants act efficiently in controlling excessive and/or accidental consumption of Se, which may occur through the use of dietary supplements that have the inorganic form of the element.

In this context, Se biofortification of carrot appears as an alternative to increase the intake of this element by the population, since an adult human is expected to ingest at least $70 \mu \mathrm{g}$ per day, with a maximum tolerable limit of $400 \mu \mathrm{g}$ (USDA, 2012).

From the results of this study, by consuming 50 $\mathrm{g}$ of fresh carrot that has been biofortified with selenite, applied through foliar application, which was the highest content of Se (14 mg kg-1 of dry mass), and considering the humidity of the carrot of $85 \%$, the daily intake of the element would be of $105 \mu \mathrm{g}$. Although this consumption is above the minimum daily requirement, the quantity is within the range of tolerable daily consumption. 

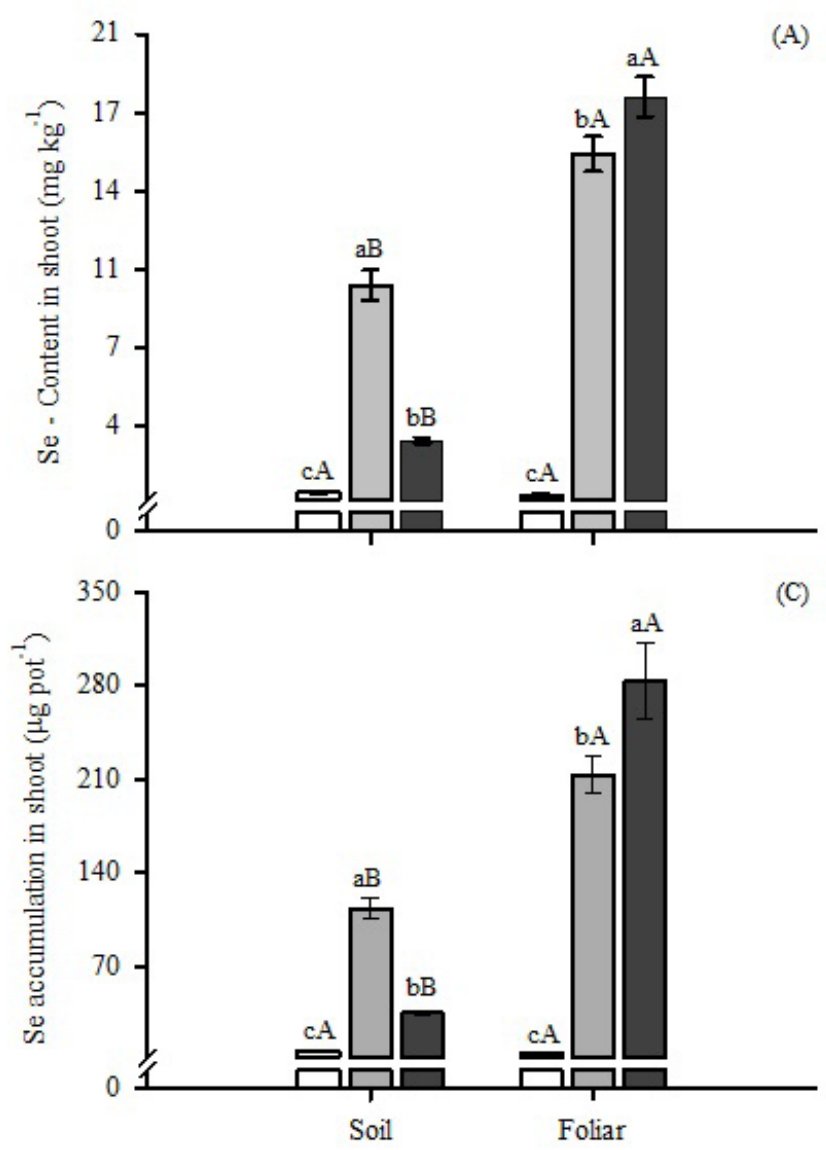

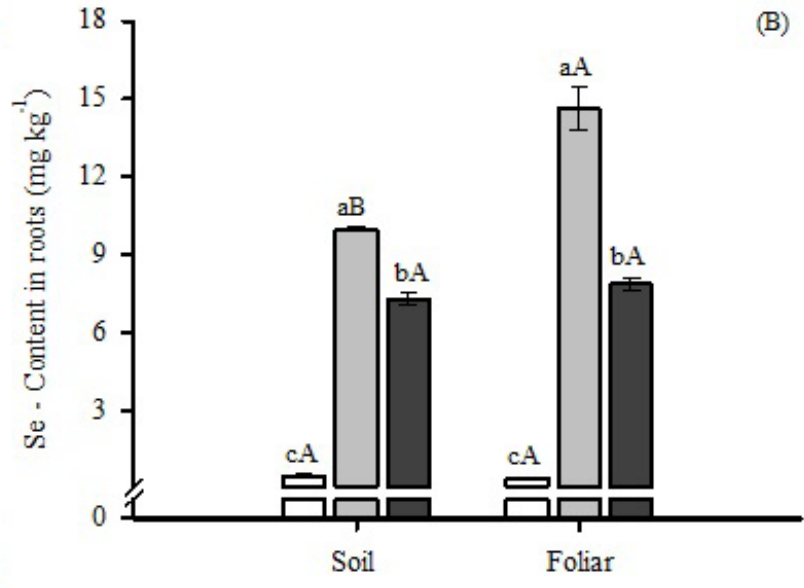

Figure 4: Se contents in the shoots $(A)$ and roots (B), and Se accumulation in the aerial part (C) of carrot plants, according to the sources and application of Se. Lowercase letters compare sources (Scott-Knott's test, p<0.05) in each application form and uppercase letters compare application forms ( $F$ test, $p<0.05$ ) in each source. Same letters mean they do not differ from each other. Vertical bar indicates the standard error of the mean $(n=5)$.

Although the results of carrot biofortification have been favorable, new studies regarding the application of the element to the crop under field conditions are still required, and further sensory tests must be done to determine if the changes in $\mathrm{pH}$ and maturation index caused by Se application are perceivable by consumers.

\section{CONCLUSIONS}

Foliar application of Se contributes to increase the production of dry mass of carrot plants. Foliar selenate increases yield, titratable acidity and reduces root maturation. When supplied via soil, selenate reduces the content of $\mathrm{K}$ in the shoot and the levels of $\mathrm{Mn}$ in the roots. When selenite is supplied via foliar application, the content and accumulation of Se in the aerial part of the plants is increased, promoting higher contents of carotenoids and reducing the $\mathrm{pH}$ of the carrot roots. The application of $\mathrm{Se}$, both through soil and foliar means, of both sources, increases its content in carrot roots. The most effective form of Se biofortification is foliar application as selenate.

\section{ACKNOWLEDGEMENTS}

The authors thank the National Council for Scientific and Technological Development (CNPq), the Foundation for Research Support of the State of Minas Gerais (FAPEMIG) and the Coordination for the Improvement of Higher Education Personnel (CAPES) for financial support and scholarships. 


\section{REFERENCES}

ALMONDES, K. G. S. et al. O papel das selenoproteínas no câncer. Revista Associação Médica Brasileira, 56(4):484488, 2010.

ASSOCIATION OF OFFICIAL ANALYTICAL CHEMISTS - AOAC. Official methods of analysis of association of Official Analytical Chemists International (18th ed.). Arlington: AOAC, 2010. 771p.

ÁVILA, F. W. et al. Impact of selenium supply on Semethylselenocysteine and glucosinolate accumulation in selenium-biofortified Brassica sprouts. Food Chemistry, 165(1):578-586, 2014.

BAÑUELOS, G. S. et al. Selenium biofortification of broccoli and carrots grown in soil amended with Se-enriched hyperaccumulator Stanleya pinnata. Food Chemistry, 166(1):603-608, 2015.

BOLDRIN, P. F. et al. Soil and foliar application of selenium in rice biofortification. Journal of Food Composition and Analysis, 31(1):238-244, 2013.

CABARAUX, J. F. et al. Effects of selenium enriched fertilizers on Se content in feedstuffs and on the selenium status in a beef cattle herd. In Proceedings of the British Society of Animal Science, York, UK, 27-29, March 2006. Available in: http://orbi.ulg.ac.be/handle/2268/35407. Acess in: July 2017.

CARTES, P.; GIANFREDA, L.; MORA, M. L. Uptake of selenium and its antioxidant activity in ryegrass when applied as selenate and selenite forms. Plant and Soil, 276(1/2):359-367, 2005.

DJANAGUIRAMAN, M. et al. Seleninm - An antioxidative protectant in soybean during senescence. Plant and Soil, 272(1/2):77-86, 2005.

DRAHONOVSKÝ, J. et al. Selenium uptake, transformation and inter-element interactions by selected wildlife plant species after foliar selenate application. Environmental and Experimental Botany, 125(1):12-19, 2016.

EMPRESA BRASILEIRA DE PESQUISA AGROPECUÁRIA EMBRAPA. Manual de métodos de análise de solo. Rio de Janeiro, 1997, 212p. (Documentos 1).

FERREIRA, D. F. Sisvar: A computer statistical analysis system. Ciência e Agrotecnologia, 35(6):1039-1042, 2011.

FILEK, M. et al. The uptake and translocation of macro- and microelements in rape and wheat seedlings as affected by selenium supply level. Plant and Soil, 336(1,2):303312, 2010.
GUERRERO, B. et al. Dual effects of different selenium species on wheat. Plant Physiology and Biochemistry, 83(1):300307, 2014.

GONZÁLEZ-MORALES, S. et al. Selenium and sulfur to produce Allium functional crops. Molecules, 558(1):122, 2017.

INSTITUTO ADOLFO LUTZ - IAL. Normas analíticas, métodos químicos e físicos para análises de alimentos. São Paulo: IAL, 2008. 1000p.

KÁPOLNA, E. et al. Effect of foliar application of selenium on its uptake and speciation in carrot. Food Chemistry, 115(1):1357-1363, 2009.

LI, H. F.; MCGRATH, S. P.; ZHAO, F. J. Selenium uptake, translocation and speciation in wheat supplied with selenate or selenite. New Phytologist, 178(1):92-102, 2008.

LOMBARDI, S. R. B.; MORAES, D. M.; CAMELATTO, D. Avaliação do crescimento e da maturação pós-colheita de pêras da cultivar Shinsseiki. Pesquisa Agropecuária Brasileira, 35(12):2399-2405, 2000.

LYONS, G. et al. Selenium concentration in wheat grain: Is there sufficient genotypic variation to use in breeding? Plant and Soil, 269(1/2):369-380, 2005.

MALAVOLTA, E. Elementos de nutrição mineral de plantas. São Paulo: Agronômica Ceres. 1980. 251p.

MALAVOLTA, E.; VITTI, G. C.; OLIVEIRA, S. A. Avaliação do estado nutricional das plantas: Princípios e aplicações. 2. Ed. Piracicaba: POTAFOS, 1997. p.319.

MARTÍNEZ, M. et al. Sorption of selenium (IV) and selenium (VI) onto magnetite. Applied Surface Science, 252(1):37673773, 2006.

MATARAZZO, P. H. M. et al. Desenvolvimento dos frutos de lulo (Solanum quitoense LAM), em Viçosa-MG. Revista Brasileira de Fruticultura, 35(1):131-142, 2013.

NASCIMENTO, R. S. M.; CARDOSO, J. A.; COCOZZA, F. D. M. Caracterização física e físico-química de frutos de mangabeira (Hancornia speciosa Gomes) no oeste da Bahia. Revista Brasileira de Engenharia Agrícola e Ambiental, 18(8):856-860, 2014.

PEZZAROSSA, B. et al. Effects of foliar and fruit addition of sodium selenate on selenium accumulation and fruit quality. Journal of the Science of Food and Agriculture, 92(1):781-786, 2012. 
RAMOS, S. J. et al. Selenium biofortification and antioxidant activity in lettuce plants fed with selenate and selenite. Plant and Soil Environment, 12(1):583-587, 2010.

RAMOS, S. J. et al. Selenium accumulation in lettuce germplasm. Planta, 233(1):649-660, 2011.

RAYMAN, M. P. The argument for increasing selenium intake. Proceedings of the Nutrition Society, 61(1):203-215, 2002.

RÍOS, J. J. et al. Nitrogen-use efficiency in relation to different forms and application rates of Se in lettuce plants. Journal of Plant Growth Regulation, 29(1):164-170, 2010.

RODRIGUEZ-AMAYA, D. B. Guide to carotenoid analysis in food. Washington: ILSI, 64p, 2001.

SILVA, A. C. B. et al. Qualidade nutricional e físico-química em cenoura (Daucus carota L.) in natura e minimamente processada. Demetra, 11(2):355-367, 2016.

SMOLEŃ, S. et al. Biofortification of carrot (Daucus carota L.) with iodine and selenium in a field experiment. Frontiers in Plant Science, 7(730):1-17, 2016.

SORS, T. G.; ELLIS, D. R.; SALT, D. E. Selenium uptake, translocation, assimilation and metabolic fate in plants. Photosynthesis Research, 86(1):373-389, 2005.

SUTTLE, N. F. Mineral Nutrition of Livestock. 4th ed. CABI: Wallingford, WC, USA, 2010. 579p. Available in: http:// www.ucv.ve/fileadmin/user_upload/facultad_agronomia/ Producion_Animal/Minerals_in_Animal_Nutrition.pdf. Acess in: July 2017.

TRESSLER, D. K.; JOSLYN, M. A. Fruits and vegetables juice processing technology. Westport: Conn. Avi., 1961, 1028p.
USDA - USDA National Nutrient Database for Standard Reference, Release 25. Nutrient Data Laboratory Home Page. U.S. Department of Agriculture, Agricultural Research Service, 2012. Available in: https://www.nal.usda.gov/fnic. Access in: May 2017.

XUE, T.; HARTIKAINEN, H.; PIIRONEN, V. Antioxidative and growth promoting effect of selenium on senescing lettuce. Plant and Soil, 237(1):55-61, 2001.

YLÄRANTA, T. Raising the selenium content of spring wheat and barley using selenite and selenate. Annales Agriculturae Fenniae, 23(1):75-84, 1984.

ZAYED, A.; LYTLE, C. M.; TERRY, N. Accumulation and volatilization of different chemical species of selenium by plants. Planta, 206(2):284-292, 1998.

ZEMBALA, M. et al. Effect of selenium on macro- and microelement distribution and physiological parameters of rape and wheat seedlings exposed to cadmium stress. Plant and Soil, 329(1):457468, 2010

ZHANG, Y. et al. Uptake and transport of selenite and selenate by soybean seedlings of two genotypes. Plant and Soil, 253(2):437-443, 2003.

ZHU, Z. et al. Effect of foliar treatment of sodium selenate on postharvest decay and quality of tomato fruits. Scientia Horticulturae, 198(1):304-310, 2016.

ZHU, Z. et al. Selenium delays tomato fruit ripening by inhibiting ethylene biosynthesis and enhancing the antioxidant defense system. Food Chemistry, 219(1):179184, 2017. 